Bénédicte Ledent, Evelyn O’Callaghan, and Daria Tunca” “'Madness Is Rampant on This Island': Writing Altered States in Anglophone Caribbean Literature", in Madness in Anglophone Caribbean Literature: On the Edge, ed. Bénédicte Ledent, Evelyn O’Callaghan, and Daria Tunca (New York: Palgrave Macmillan, 2018), pp. 1-17. https://doi.org/10.1007/978-3-319-98180-2_1

\title{
"Madness Is Rampant on This Island": Writing Altered States in Anglophone Caribbean Literature
}

Bénédicte Ledent, Evelyn O’Callaghan, and Daria Tunca

\section{Centuries of Crazy}

Two novels shortlisted in the fiction category for the 2017 NGM Bocas Literary Prize are explicitly concerned with madness and altered states of being. In Marcia Douglas's The Marvellous Equations of the Dread (2016), a witness observes of Jamaica that " $[\mathrm{m}]$ adness is rampant on this island. The mad dream dreams and have visions. They stand on street corners and tell it" (76, italics in original). Some of these visionaries, it transpires, are, in fact, temporarily embodied ancestral spirits returned to earth to intervene in their society's implosion. But as the witness also notes, “No one listens” (76, italics in original). In Kei Miller's overall prize-winning Augustown (2016), however, people do listen. They listen to the preacher, Bedward, who has the gift of flight but, as history records, ends up committed to a lunatic asylum. It is madness, of course, to think that the spirits of the dead can and do return to our material reality and communicate with humans, or that humans can fly. Or is it? How do we critically analyse representations of a Caribbean world, such as occur in these two texts, which matter-of-factly include possession, states of transformation, visions and warnings from unknown sources, communication with spirits, and the rising of bodies into the sky as part and parcel of everyday life?

The Caribbean has, throughout its history, been represented as an exotic, odd, and somewhat suspect space whose "natives” believe and act in strange (that is, non-Western) ways. The cruelty of enslavement and colonialism that created the people of the region and its peculiar social structure in many ways warped those who inhabited the space, so that even supposedly civilized and rational Euro-Americans living there started to change: to go crazy, to "go native," to go mad. Early commentators blamed this instability on the climate, the culture, the purportedly degenerate Creoles and allegedly savage Africans, the heathen "Hindoos"; and yet it was likely something generated by the extraordinarily violent excesses 
Bénédicte Ledent, Evelyn O’Callaghan, and Daria Tunca” “'Madness Is Rampant on This Island': Writing Altered States in Anglophone Caribbean Literature", in Madness in Anglophone Caribbean Literature: On the Edge, ed. Bénédicte Ledent, Evelyn O’Callaghan, and Daria Tunca (New York: Palgrave Macmillan, 2018), pp. 1-17. https://doi.org/10.1007/978-3-319-98180-2_1

Status: Postprint (Authors' version)

of the region: fabulous wealth and privilege, unbearable suffering and subjection, heroic resistance and brutal suppression of human rights. In Frieda Cassin's early novel, With Silent Tread (1890), the English Selwyn expects his Antiguan cousin Morea to be short and yellow, "utterly incapable of helping herself” without "six or seven black maids lolling about," indolent, drawling, and fond of giving orders (116). After all, as far as he is concerned, she comes from a "topsy-turvy land with fishes that fly, and crazy cashews growing their seeds outside instead of in" (125). The Caribbean is a "topsy-turvy" site of difference, and difference is viewed from England as a sign of degeneracy-physical, racial, mental, and moral.

In this collection, however, we turn to how Caribbean writers, including diasporic ones, configure this space of difference in more nuanced terminology; and in doing so, we push beyond seeing the Caribbean as a deranged space to regarding it as one that accommodates altered states of consciousness. Taking as its main starting point the pervasive representation of various forms of mental illness, breakdown, and psychopathology in Caribbean literature and the recurrence of "mad" characters and allusions to insanity, the present volume also notes that these topics have been relatively neglected in criticism, especially in the Anglophone sphere, apart from the scholarship devoted to Jean Rhys's Wide Sargasso Sea (1966), a work which has become iconic in any discussions of literary constructions of mental aberration in the Caribbean, perhaps even the postcolonial world.

While one must acknowledge a small number of recent publications on the topic, such as Kelly Baker Josephs's Disturbers of the Peace: Representations of Madness in Anglophone Caribbean Literature (2013) and Caroline A. Brown and Johanna X.K. Garvey's edited collection Madness in Black Women's Diasporic Fictions: Aesthetics of Resistance (2017), it is undeniable that much remains to be done in rethinking the trope of "madness" across Anglophone Caribbean literature. Reviewing Baker Josephs's study, Sheri-Marie Harrison asks a question similar to that which, years ago, prompted the present research project: "The proliferation of mad characters in Caribbean fiction at large makes it puzzling that we were a decade into the twenty-first century before the publication of a critical study dedicated entirely to this ubiquitous literary trope." If Disturbers of the Peace is a milestone in this long-neglected field, Baker Josephs's book, by its own account, is narrowly focused on the “repetition of madness in Caribbean literature written in English between 1959 and 1980" (1), and its scant references to more recent writing are left until the Epilogue, which briefly deals 
Bénédicte Ledent, Evelyn O’Callaghan, and Daria Tunca” “'Madness Is Rampant on This Island': Writing Altered States in Anglophone Caribbean Literature", in Madness in Anglophone Caribbean Literature: On the Edge, ed. Bénédicte Ledent, Evelyn O’Callaghan, and Daria Tunca (New York: Palgrave Macmillan, 2018), pp. 1-17. https://doi.org/10.1007/978-3-319-98180-2_1

Status: Postprint (Authors' version)

with novels published in the twenty-first century, such as David Chariandy's Soucouyant (2007), Marie-Elena John's Unburnable (2006), and Zadie Smith's White Teeth (2000). Moreover, the texts that Baker Josephs addresses in the body of her book, by such writers as Derek Walcott and Sylvia Wynter, to mention just a few, are chosen with a specific focus in mind: madness as "providing different viewpoints on decolonization" and the project of nation building (17). The remit of Brown and Garvey's collection is also neatly circumscribed, as it centres on the way women fiction writers from the African diaspora at large, not just the Caribbean, have used madness — or what is regarded as such—not only as "a metaphor for the dispossession felt by individual characters" but also as "a pivotal aesthetic strategy that will force new ways of reading, engaging, and understanding history as both ancient past and active present” (Brown 9). In her conclusion to the volume, Garvey also reminds us of the subversive potential of mental disorder, which, in the postcolonial context, can function "as marooning and resistance, a refusal of assimilation to the order/sanity/control of a system of oppression” (294). Unsurprisingly, Garvey refers in these concluding remarks to Evelyn O’Callaghan's work, which, in the 1990s, reached similar findings in its examination of a selection of literary madwomen in West Indian literature through the lens of R.D. Laing's psychoanalytical study of schizophrenia. O'Callaghan's early publications in the field, notably her essay entitled "Interior Schisms Dramatized," are part of a limited number of studies released before 2013, mostly in the form of articles. These have paved the way for the present project, as they convincingly demonstrate the centrality of the theme of madness in any attempt to understand the specificities of Caribbean culture, in spite of the relative absence of questions of mental health from literary critical radars.

It is useful at this juncture to highlight the most relevant of these interventions, penned by established critics. Isolated though these are, they have provided us with significant epistemological stepping stones for negotiating this still under-investigated field. In "The Madman at the Crossroads,” J. Michael Dash, drawing on Edouard Glissant, sees the raving figure of the madman as a symbol of the Caribbean's radical, unpredictable otherness, and views "this manifestation of madness ... [as] an exemplary state of extreme consciousness ... and not as a form of pathological behavior” (41). There is something equally disturbing but also subversively daring in Alison Donnell's understanding of the region as "queer," a term that is usually associated with sexuality and gender but, in Donnell's reasoning, also refers to a place marked by a more general interrogation of normativity, an approach that she has 
Bénédicte Ledent, Evelyn O’Callaghan, and Daria Tunca” “'Madness Is Rampant on This Island': Writing Altered States in Anglophone Caribbean Literature", in Madness in Anglophone Caribbean Literature: On the Edge, ed. Bénédicte Ledent, Evelyn O’Callaghan, and Daria Tunca (New York: Palgrave Macmillan, 2018), pp. 1-17. https://doi.org/10.1007/978-3-319-98180-2_1

Status: Postprint (Authors' version)

developed in relation to various Caribbean writers, for example Trinidadian Shani Mootoo. Another critical text that has fed into our research is Michael Gilkes's 1986 lecture, significantly entitled “Creative Schizophrenia: The Caribbean Cultural Challenge,” in which the Guyanese critic starts from the racial and cultural "fragmentation and dissociation of Self" (1) and regards this potentially paralysing disorder as "the most damaging legacy of colonization" (1-2). While, as Frantz Fanon has famously shown in Black Skin, White Masks (1967), this ambivalent state has been the source of much suffering for the formerly colonized, it is also, Gilkes argues, a gateway for the creative imagination, as demonstrated by many literary works of the Caribbean literary tradition. One such text is Derek Walcott's play Dream on Monkey Mountain (1970), which is extensively covered by Baker Josephs in Disturbers of the Peace. Dream is also tackled by John Thieme, alongside Erna Brodber's Jane and Louisa Will Soon Come Home (1980) and Earl Lovelace's Salt (1996), as well as other works by French-speaking Caribbean writers, in an article that appeared in an edited collection devoted to madness in postcolonial literature (Zinato and Pes, which also includes a study by Francesca Scalinci on the representation of insanity in Roger Mais's The Hills Were Joyful Together [1953]). For Thieme, the books he addresses are some of multiple examples of how "both Europe and Africa ... have combined together to create a condition of 'nervous' dissociation in the Caribbean subject's mind" (98). Worth mentioning too are a few dissertations, including Letizia Gramaglia’s "Representations of Madness in Indo-Caribbean Literature” and James McCrink’s “Imperial Illness: Considering the Trope of Madness in Michelle Cliff's No Telephone to Heaven.” However incomplete, this survey nevertheless suggests that most of the existing criticism in the field revolves around notions of excentricity and cultural dissociation.

\section{Why the Caribbean?}

The painful history of the Caribbean is inextricably linked with writers' representations (and critical theorizations) of psychic distress. This collection is not to be read as a historical or psycho-sociological overview of the literature of the region, but we feel that gesturing to the context of its peculiar past may help shed light on a place where "non-normative" behavioural patterns might be said to have been regularly incorporated into creative writing since, say, the nineteenth century, and are therefore presented, by and large, as unremarkable. Certainly, a legacy of forced servitude, displacement, and violence resulted in an ontological trauma that 
Bénédicte Ledent, Evelyn O’Callaghan, and Daria Tunca” “'Madness Is Rampant on This Island': Writing Altered States in Anglophone Caribbean Literature”, in Madness in Anglophone Caribbean Literature: On the Edge, ed. Bénédicte Ledent, Evelyn O’Callaghan, and Daria Tunca (New York: Palgrave Macmillan, 2018), pp. 1-17. https://doi.org/10.1007/978-3-319-98180-2_1

Status: Postprint (Authors' version)

still manifests in what some perceive as contemporary Caribbean neuroses regarding identity, which are articulated in literary, theoretical, philosophical, and political discourses. It is important to note that there may be an overlap between the traumatized subject of violence and of subjection, on the one hand, and the traumatized subject of colonial identity politics, on the other, but in some cases the crises they provoke may also be distinct. Displacement, the cruelty and dehumanization of plantation slavery and indentureship, and the colonial legacy of dis-ease with who Caribbean people are and where they belong contribute to an absence of holistic security with devastating psychological consequences for individuals, communities, and national cultures, a condition detailed by Frantz Fanon, as mentioned above. Given the deeply fractured sense of ontological security of the consistently marginalized and persecuted, the evidence explaining why the Caribbean is a pathological site of endemic derangement is strong in this regard.

While such mental confusion seems pervasive in narratives set during the colonization and decolonization periods, one may wonder why writers today are still revisiting the repercussions of these wounds in the twenty-first century. Is it partly because of further and continuing displacement (in the diaspora), different visitations of violence (domestic abuse, political tribalism, punishment of alternative sexualities), or new crises of subject formation for Caribbean subjects who crave acceptance despite, not at the expense or in denial of, their difference? In any case, notwithstanding the negative depiction of the psychic consequences of historical, political, race, class, and gender inequities which impinge on the psychic health and emotional well-being of colonial and early postcolonial subjects, the temptation must be resisted to pathologize the Caribbean as essentially a site of derangement. Further, as already suggested above, there is, in the literature, a distinction between the evocation of madness and of altered states: that is, between psychic injury and what might be described as "possession" by an external force, not necessarily with one's approval. Any pretence at tracing the causes and roots of psychic disturbance as depicted in literary texts overlooks what these expressions of altered consciousness also signify in terms of a refusal to comply with the rational consensus and worldview normalized by explanatory narratives overwhelmingly from the global north-including science, religion, and imperialism. Could what passes for madness actually be something other, such as resistance to the truly demented logic of race, class, and gender prejudice enshrined in the popular consciousness of Caribbean societies? Could it represent states of transcendence embedded in alternative cosmologies or an enraged psyche 
Bénédicte Ledent, Evelyn O’Callaghan, and Daria Tunca” “'Madness Is Rampant on This Island': Writing Altered States in Anglophone Caribbean Literature", in Madness in Anglophone Caribbean Literature: On the Edge, ed. Bénédicte Ledent, Evelyn O’Callaghan, and Daria Tunca (New York: Palgrave Macmillan, 2018), pp. 1-17. https://doi.org/10.1007/978-3-319-98180-2_1

Status: Postprint (Authors' version)

boldly repudiating the terms on which human consciousness is shaped and managed around limiting and imposed expectations of the "normal"? Setting themselves almost beyond conventional interpretation, textual evocations of such states are as extensive in their choice of subject as the range of narrative experimentation they employ. The insistent refusal of closure, certainty, and stability to which these writings draw attention may be an expression of, and insistence on, the validity of difference, but they also engage profoundly with the dominant discourses and the various epistemological frameworks that have helped to characterize Caribbean cultures, such as creolization. Neither fully African nor Indian nor English nor Scottish, but a new subjectivity out of several or all; neither black nor white nor Asian nor Amerindian, but a new subjectivity out of several or all: Caribbean subject formation refuses monolithic categories, including "mad" or "sane." Indeed, the states of madness depicted in literature also offer a space of political, cultural, and artistic resistance and, seemingly paradoxically in some cases, a means of agency or even healing. In short, we want to do what Harrison claims for Disturbers of the Peace in her review: to ask what it is that "the work madness does in Caribbean literature" without recourse to "formulaic and worn assumptions” (9).

The present volume asks how focusing on literary manifestations of apparent mental aberration or extremity can extend our understanding of Caribbean narrative and culture as a whole. In so doing, the book helps us to interrogate the norms that have been used to categorize art from the region, and it contributes to contextualizing the boundaries between notions of rationality, transcendence, and insanity across cultures. The prevalence of the madness trope in Caribbean literature suggests a constant grappling with inherited and imposed notions of normalcy and an inherent challenge to the borders of knowledge and experience. By situating our study "on the edge," we want not only to gesture to the states of anxiety, anguish, or hyperawareness that characterize the psychological conditions discussed within its pages, but also to draw attention to the intention of our project, which attempts both to move beyond the existing analyses of madness in Caribbean literature and to cross the strictly disciplinary limits of the literary field when necessary. Whereas it is vital to keep options open for how madness and other altered states are determined in reading Caribbean literature and culture, it bears repeating that we take very seriously the legacy of psychic injury from the historical abuse of colonialism-physical, sexual, and psychologicalinflicted on the lives of people in the region, generation after generation, as testified to in the 
Bénédicte Ledent, Evelyn O’Callaghan, and Daria Tunca” “'Madness Is Rampant on This Island': Writing Altered States in Anglophone Caribbean Literature”, in Madness in Anglophone Caribbean Literature: On the Edge, ed. Bénédicte Ledent, Evelyn O’Callaghan, and Daria Tunca (New York: Palgrave Macmillan, 2018), pp. 1-17. https://doi.org/10.1007/978-3-319-98180-2_1

Status: Postprint (Authors' version)

texts and critical material with which these essays engage. In taking this approach, we concur with John Thieme, who in the abovementioned article declines "to suggest that madness is not a clinical condition” (95). Yet literary evocations of its multiple manifestations go far beyond the clinical, and this collection accordingly expands the term beyond depictions of psychiatric disorders. In fact, only a handful of texts, like Ingrid Persaud's If I Never Went Home (2013) or David Chariandy's Soucouyant, actually name and describe specific conditions such as depression and dementia. Rather, with Thieme, most writers and certainly the editors of this volume recognize that madness "starts from the Foucauldian premise that its definitions [sic] is culturally constructed, a discursive formation, in which a group, usually a dominant group, designates deviations from its supposed norms as 'mad'” (1). Further, we take on board Dash’s assertion in "The Madman at the Crossroads" that, as literary scholars, there is a need now to re-examine the postcolonial appropriation of the Caribbean as a "zone of radical juxtaposition and unpredictable synthesis, where the associated processes of mestizaje, creolization, liminality and so on flourish” (37) and perhaps to query the stereotyped linking of hybrid places with a "salutary derangement of the senses" (40). Indeed, citing Alison Donnell again, the Caribbean is “a queer place," and this surfaces in textual evocations of strange states that must be taken in their own contexts, however pathological these may appear to a religiously conservative and homophobic percentage of people in the Caribbean and elsewhere.

Bearing in mind these theoretical and critical clarifications and queries, which implicitly inform the present project, we organize the volume into three sections, each gesturing towards developments in assessing scholarly engagements with the subject matter.

\section{Part One: Madness Reconsidered}

The chapters in this section reconsider some of the deranged figures who populate Caribbean literature: the beggar at the crossroads, the alienated white creole, the angry black woman, and the neurotic migrant in the metropolis-figures that constantly invite us to reassess the slippery meaning of such words as "mad," "madness," and a semantically associated lexicon. The chapters in this section feature characters who are on the cusp of normative behaviour or have slipped over the edge into dysfunctionality. These contributions underline the way the narratives situate the reader in relation to such characters, whether using their plight to embody the primary concerns of the writers or as an indictment of alienating and hostile 
Bénédicte Ledent, Evelyn O’Callaghan, and Daria Tunca” “'Madness Is Rampant on This Island': Writing Altered States in Anglophone Caribbean Literature”, in Madness in Anglophone Caribbean Literature: On the Edge, ed. Bénédicte Ledent, Evelyn O’Callaghan, and Daria Tunca (New York: Palgrave Macmillan, 2018), pp. 1-17. https://doi.org/10.1007/978-3-319-98180-2_1

Status: Postprint (Authors' version)

environments, at home and in the diaspora. Featuring protagonists who withdraw into fantasy, fury, or silence, these chapters argue that madness as a means of transgressing respectability, exploring subjectivity, and even as abandonment neurosis offers a space from which human subjects are able to refuse an inadequate offer of social and psychological accommodation. As Baker Josephs puts it in her contribution to this volume, the "'continuum' of crazy is magnified," which leads to the "difficulty of describing madness within 'the language of reason."” How, the contributions to this section ask, is madness articulated, how is it labelled, and within what kind of discourse can we come to better understand its potential for questioning the accepted harm of everyday life?

Consistently, the European colonization of the Caribbean and the entrenched colour, class, and gender hierarchies that are its legacy emerge as factors in the disintegration of fictional characters. Opening with a well-known, mentally challenged female figure of the Jamaican street festival "Passa, Passa,” Kelly Baker Josephs’s essay, “'Kingston Full of Them': Madwomen at the Crossroads,” zooms in on this woman's fictional counterparts, as represented in five late twentieth-century literary texts, either poems or short stories, by Slade Hopkinson, Roger McTair, Jean “Binta” Breeze, Olive Senior, and Marcia Douglas. Baker Josephs's argument is that these conspicuous Kingstonian madwomen "function as markers of both cultural and social geographies.” Beyond their very concrete tragedies, these characters generate a reflection on the weight of respectability burdening Caribbean women in urban spaces and, more generally, symbolize the gender prejudices that are still rife in a culture very much influenced by its legacy of slavery and colonial rule. Denise deCaires Narain's contribution too has a gendered dimension in that it addresses, via the work of Frantz Fanon and Judith Butler, how Jean Rhys and Jamaica Kincaid react to patriarchal hegemonies in their respective autobiographical and fictional writings. "Madness" and "rage" are words that have often been used by critics to describe the temperament of Rhys and Kincaid themselves as well as that of their fictional characters. In her chapter, “Fighting Mad to Tell Her Story”: Madness, Rage, and Literary Self-Making in Jean Rhys and Jamaica Kincaid,” deCaires Narain shows how these two writers subvert such prejudiced ascriptions and energize postcolonial rage, with a resonance that goes well beyond their literary production and involves "a complicated meditation on self-making as an ongoing and precarious matter." Existential questions are also at the heart of Ping Su's exploration of "madness" in Caribbean literature. More specifically, she discusses two novels by Caryl Phillips, A Distant Shore 
Bénédicte Ledent, Evelyn O’Callaghan, and Daria Tunca” “'Madness Is Rampant on This Island': Writing Altered States in Anglophone Caribbean Literature", in Madness in Anglophone Caribbean Literature: On the Edge, ed. Bénédicte Ledent, Evelyn O’Callaghan, and Daria Tunca (New York: Palgrave Macmillan, 2018), pp. 1-17. https://doi.org/10.1007/978-3-319-98180-2_1

Status: Postprint (Authors' version)

(2003) and In the Falling Snow (2009), and focuses on two mentally deranged characters, a white English woman in the former text and a first-generation Caribbean immigrant in the latter, both apparently helpless victims of a sexist and racist society. Su demonstrates, however, that the abandonment neurosis from which these protagonists suffer paradoxically paves the way to a form of healing that is achieved through strategic silence and withdrawal and is therefore indicative of some modicum of agency.

\section{Part Two: Madness as Methodology}

In this section, "madness" is no longer only a thematic focus but is expanded to incorporate a consideration of methodological strategy. The chapters here employ narratological, ecocritical, and psycho-historical readings of well-known Caribbean texts to focus on "madness" no longer as a trope linked to oppression or the resistance to it, as is the case in some contributions to the present volume, but as the textual enactment of a form of madness with meaningful ramifications. In other words, the reading process in this section oscillates, in a sense, on the edge of both formal and content assessment. Delphine Munos, in "Speaking of Madness in the First Person/Speaking Madness in the Second Person? Junot Díaz's The Brief Wondrous Life of Oscar Wao and 'The Cheater's Guide to Love'," examines how the employment of second-person (and first-person) narration in texts by the same author shifts the ways in which Caribbean hyper-masculinity can be perceived as a form of mental derangement rather than celebrated as a mode of empowerment. More specifically, Munos highlights how Díaz's implementation of what Shoshana Felman has called a "rhetoric of madness" impacts on the reader's perception of "the hidden complicities and hierarchies of power" that are involved in the protagonist's flaunting of his excessive masculinity. Gender is also crucial to the other novels discussed in the next two chapters, but these, nevertheless, adopt other interpretational lenses. Carine M. Mardorossian, in “What Is 'Worse Besides’? An Ecocritical Reading of Madness in Caribbean Fiction,” addresses Jean Rhys’s Wide Sargasso Sea and Shani Mootoo's Cereus Blooms at Night (1996). Mardorossian starts from the premise that the alleged madness of these books' respective characters is a potentially problematic aspect of fictional depiction in the sense that it suggests a form of unidimensionality, limiting our access to the protagonists' self-consciousness. However, when the mental derangement of the protagonists is read in association with the surrounding landscape, this leads to a deeper and more sympathetic appreciation of their humanity. In 
Bénédicte Ledent, Evelyn O’Callaghan, and Daria Tunca” “'Madness Is Rampant on This Island': Writing Altered States in Anglophone Caribbean Literature", in Madness in Anglophone Caribbean Literature: On the Edge, ed. Bénédicte Ledent, Evelyn O’Callaghan, and Daria Tunca (New York: Palgrave Macmillan, 2018), pp. 1-17. https://doi.org/10.1007/978-3-319-98180-2_1

Status: Postprint (Authors' version)

other words, adopting a reading strategy that associates the non-human environment with madness gives readers access to the minds of individuals who are "gifted with an insight and a complex understanding of power relations.” Writing on "Performing Delusional Evil: Jamaica Kincaid's The Autobiography of My Mother," Rebecca Romdhani considers the narrative unreliability of a fictional character whose maniac tendencies, in spite of her status as one of the colonized, emerge in complex and challenging ways, as ventriloquisms of colonialist attitudes. Madness, here, is not the expression of the mental imbalance of a colonized individual who has been damaged by the confrontation with the horrors of colonization, slavery, or migration, but it provocatively evokes the collective, delusional nature of the colonizer's view of history, an approach to the past that is marked by a lack of remorse, guilt, and empathy.

\section{Part Three: From Madness to Altered States}

Dialoguing with texts and theories concerning affective and mental states that operate on planes other than the rational and the material — the so-called "real" - this section explores altered states of consciousness which call into question and indeed transcend any confident calibration of the sane and insane. The fictional texts discussed here deal with characters who experience states of possession and of transcendence, protagonists who foresee the future or relive the past, and who, as a result, are often (erroneously?) perceived as mad because such experiences cannot be explained otherwise. The link between "madness" and seeing differently points towards the varied interpretations which the contributors bring to the subject of altered states. Widely divergent spiritual and epistemological systems coexist in the Caribbean, and different cosmologies are accommodated, resulting in what commentators have termed its syncretic, hybrid culture. Again, the essays here are on the edge, this time of terminology itself and of confidence in the very idea of $a$ norm from which madness deviates. The writings addressed in this section detail states of consciousness which hover somewhere between psychosis and inspiration, delusion and transfiguration, breakdown and possession.

In “Horizons of Desire in Caribbean Queer Speculative Fiction: Marlon James’s John Crow's Devil," Michael A. Bucknor argues that Caribbean speculative fiction constructs a queer epistemological practice that questions the disavowal of the magical in the real. Drawing together the genre of magical realism, the sexual subject position of queerness, and the socio-psychological state of madness to situate readers on the border of what is considered 
Bénédicte Ledent, Evelyn O’Callaghan, and Daria Tunca” “'Madness Is Rampant on This Island': Writing Altered States in Anglophone Caribbean Literature", in Madness in Anglophone Caribbean Literature: On the Edge, ed. Bénédicte Ledent, Evelyn O’Callaghan, and Daria Tunca (New York: Palgrave Macmillan, 2018), pp. 1-17. https://doi.org/10.1007/978-3-319-98180-2_1

Status: Postprint (Authors' version)

"normal," this chapter calls attention to the importance of epistemological orientation, to ways of seeing, as the ultimate determining factors in plotting the location of normal and deviant. Lest we think, however, that such cartography allows for complete relativism, Bucknor insists that just as magical realist texts are subject to the rules of the genre, so discourses of madness and queerness are bounded by larger considerations of justice and ethics.

Alison Donnell, in “When Seeing Is Believing: Enduring Injustice in Merle Collins’s The Colour of Forgetting," suggests that the figure of Carib in Collins's novel embodies the inscrutable presence of the indigenous Caribbean voicing a sentience of transgenerational dispossessions from land and history that cannot otherwise be heard. Drawing on political philosopher Jeff Spinner-Halev's concept of enduring injustice and his call to focus on injustices rooted in the past as a means to understand and address contemporary wrongs, Donnell argues for Carib’s extraordinary memory of violence: histories of enslavement, colonialism, and plantation labour that have compromised co-belonging as a means to approach the imploded Grenada Revolution in 1983. Carib’s poetic “warnings” are considered by most listeners to be incomprehensible, but, in fact, they link together the different manifestations of the recurrent land dispossession trauma and offer a way forward.

Evelyn O’Callaghan’s chapter on “Migrant Madness or Poetics of Spirit? Teaching Erna Brodber and Kei Miller” focuses on writings which depict altered states such as spirit possession, visions, inspired warnings, and prophesying, phenomena which are taken for granted in Caribbean spiritual practice but are regarded in the diaspora as abnormal and inappropriate, possibly indicative of mental illness. As the editors of Excentric Writing remind us, it was Foucault who observed that such judgments have their basis in "the Cartesian assumption of insanity's incompatibility with thought and truth" (Zinato and Pes, “Introduction” 2, our italics). Accordingly, the very states that manifest amongst believers and signal transcendence in churches and tents and balmyards and tonnelles in the Caribbean are viewed with suspicion, if not fear, in other societies and constitute grounds for forcible containment. The chapter explores how the writings of Brodber and Miller configure the performance of transcendence and the reception accorded such manifestations both within and outside the region.

Finally, Rebecca Romdhani’s “(Re)Locating Madness and Prophesy” is an interview with Kei Miller, a Caribbean writer who has tackled in his work many of the issues raised in the present volume. Commenting on the frequency with which one encounters "mad" men or 
Bénédicte Ledent, Evelyn O’Callaghan, and Daria Tunca” “'Madness Is Rampant on This Island': Writing Altered States in Anglophone Caribbean Literature”, in Madness in Anglophone Caribbean Literature: On the Edge, ed. Bénédicte Ledent, Evelyn O’Callaghan, and Daria Tunca (New York: Palgrave Macmillan, 2018), pp. 1-17. https://doi.org/10.1007/978-3-319-98180-2_1

Status: Postprint (Authors' version)

women on the streets of Port of Spain, Kingston, and several Caribbean city centres, or rather people exhibiting apparent signs of mental illness or of psychic fragmentation, Miller talks about writing such figures from the inside, imagining “what has been unplugged in them.” He then discusses the relationship between madness and diaspora, suggesting that migrants' attempt to re-create their home in a new country — as colonizers did before them-is also a form of madness. Miller's insightful reflection on his craft and on the people and places that inspire it is a fitting complement to the textual analyses that make up the bulk of this collection.

\section{The Roads Not Taken}

It hardly needs saying: inevitably, in any collection of essays on a subject this broadly interpreted, some omissions do occur. The scope of this volume precluded the kind of inclusivity we would have hoped for, as only a certain number of writers could be dealt with. But other texts and authors could have been included. For instance, the writings of Edgar Mittelholzer, and perhaps his life story, suggest promise for further investigation into our chosen topic. Similarly, many of Earl Lovelace's fictions feature characters on the edge, and madness is a recurrent theme in his work. Other writers that come to mind are Garth St Omer and Roy Heath. Meanwhile, generically, there is an emphasis on fiction and, to some extent, poetry to the exclusion of drama. That said, contemporary critical scholarship on Caribbean drama is fairly thin, partly because the writing, directing, and performing of plays in the Anglophone region is much less common than it was in the late twentieth century. If one compares the focus of conference papers at, say, the Annual Conference on West Indian Literature, or the literary panels of the Caribbean Studies Association, or the Society for Caribbean Studies, the ratio of fiction, poetry, popular culture, and film to drama is instructive. Nonetheless, a number of Caribbean plays would certainly deserve to be analysed in the context of a study of “madness.” Derek Walcott's Dream on Monkey Mountain, first produced in 1967, is obviously a case in point, as already suggested above in the short survey of the existing criticism. Thus, it is not surprising that, as mentioned, it should be one of the main texts discussed by Baker Josephs in her Disturbers of the Peace where she focuses on the links between dreams and madness as ways for the mind to "envision change.” The former conveys positive visions of an alternative reality and the latter negative distortions of the characters' anxieties about race and identity. Analysed by John Thieme as a "brilliant 
Bénédicte Ledent, Evelyn O’Callaghan, and Daria Tunca” “'Madness Is Rampant on This Island': Writing Altered States in Anglophone Caribbean Literature", in Madness in Anglophone Caribbean Literature: On the Edge, ed. Bénédicte Ledent, Evelyn O’Callaghan, and Daria Tunca (New York: Palgrave Macmillan, 2018), pp. 1-17. https://doi.org/10.1007/978-3-319-98180-2_1

Status: Postprint (Authors' version)

dramatization of the dissociated Caribbean psyche” (96), of how difficult it is for Caribbean people to cope with the clash between European and African legacies, Dream on Monkey Mountain has also been interpreted by Erskine Peters who views in Makak, the play's main character, a victim of a form of "historical imprisonment" (149), which has nefarious effects on his sense of self. Like Walcott's play, Una Marson's Pocomania (staged at the Ward Theatre in Kingston in January 1938) also dramatizes the cultural, racial, and class divides that pervaded early twentieth-century Caribbean societies. In her introduction to the reissue of this work, Alison Donnell notes how the central female character Stella's "attachment to Pocomania [translated as "little madness"] and the associated practices of Revivalism, spirit possession, the balm yard, and ultimately of Africa-all of which were feared and reviled by middle-class Jamaica — dramatizes her desire to breach her deadening but socially-obligated alignment with colonial culture” (xx). It is significant, as Donnell points out, that although the play ends with Stella's apparent return to middle-class respectability, she and her future husband agree to ensure that their life together can accommodate "a little madness," once again highlighting the continuum of cultural positions on madness and rationality in the Caribbean. Among other dramatic pieces that would benefit from being read through the lens of psychological disruption are Caryl Phillips's plays which address the mental toll of displacement on the first generation of Caribbean migrants to Britain, which is another island where, in reference to the title of this introduction, madness might be said to be "rampant" as well. Vivien, the mother in Strange Fruit (1981), buckles under the psychological weight of having raised two sons on her own and faced humiliating discrimination, while Albert, the protagonist of Where There Is Darkness (1982), is pathologically divided between his native Caribbean, to which he is about to return, and the England where he has spent more than 20 years. Both Vivien's and Albert's eventual breakdown is clearly linked to their outsider status in a mother country which has failed to recognize them, in a place where, according to Albert, "if a person have a little sickness in the head they send people to come lock them up like they is criminal" (51).

Clearly, the selection of texts discussed in this volume cannot be exhaustive; similarly, the contributions could have been grouped according to other foci than those we have chosen. For example, a concern with gender links the pieces by Baker Josephs, deCaires Narain, Munos, Bucknor, and some of O’Callaghan's. The influence of transplantation to the diaspora on representations of madness is obvious in both Su's discussion of Caryl Phillips's fiction 
Bénédicte Ledent, Evelyn O’Callaghan, and Daria Tunca” “'Madness Is Rampant on This Island': Writing Altered States in Anglophone Caribbean Literature”, in Madness in Anglophone Caribbean Literature: On the Edge, ed. Bénédicte Ledent, Evelyn O’Callaghan, and Daria Tunca (New York: Palgrave Macmillan, 2018), pp. 1-17. https://doi.org/10.1007/978-3-319-98180-2_1

Status: Postprint (Authors' version)

and O'Callaghan's study of Miller's work. And such categories-that is, gender and diaspora-could be made to overlap. So, for instance, fiction by Caribbean women, such as Erna Brodber's novel Myal (1988) and Joan Riley's The Unbelonging (1985), as well as others by Francophone Caribbean women, such as Myriam Warner-Vieyra's As the Sorcerer Said (1982) and Marie-Célie Agnant's The Book of Emma (2006), features ontologically insecure Caribbean girls, vulnerable and lacking parental support, who are pushed over the edge by displacement. Diaspora reinforces their experiences of difference, unbelonging tips the balance in their psychic health, and their isolation prevents them from seeking help. Interestingly, while for the majority, withdrawal into a semi-catatonic state serves as a mode of defence against further betrayal by a male other who commodifies them and renders them “what other people say I am” (Rhys, Wide Sargasso Sea 39), Rhys’s Antoinette in Wide Sargasso Sea emerges at the end as what deCaires Narain calls "fighting mad.” Diaspora then plays out as the stage for the fictional characters' solution to an intractable ontological condition for some Caribbean women.

All of these possible directions for reading madness in Caribbean literature that could not be developed in this collection do not undermine the valuable contribution of the essays we offer here to this vexing and fascinating subject. Difficult to pin down, madness in the writing discussed is-as noted - a richly evocative and often contradictory trope, culturally constructed and often eluding precise depictions and blurring interpretative lenses. The depiction of an altered state of consciousness in deranged or "touched" characters evokes pathos, rage, pity, inspiration, even awe. We have tried to avoid only concentrating on how writers appropriate dysfunctional or spiritual states of madness to instead emphasize underlying historical or political issues, and we have encouraged the contributors to be as creative in their analyses as the texts that inspired them. We await with anticipation the next round of contributions to this strange but urgent strand in the tapestry of Caribbean literature and look forward to a constructive dialogue in what promises to be a fertile field of research.

\section{Works Cited}

Agnant, Marie-Célie. The Book of Emma. Trans. Zilpha Ellis. Toronto: Insomniac, 2006. Print. Trans. of Le Livre d'Emma. Montréal: Remue-ménage, 2001. Print.

Brodber, Erna. Jane and Louisa Will Soon Come Home. London: New Beacon, 1981. Print. . Myal. London: New Beacon, 1988. Print. 
Bénédicte Ledent, Evelyn O’Callaghan, and Daria Tunca” “'Madness Is Rampant on This Island': Writing Altered States in Anglophone Caribbean Literature", in Madness in Anglophone Caribbean Literature: On the Edge, ed. Bénédicte Ledent, Evelyn O’Callaghan, and Daria Tunca (New York: Palgrave Macmillan, 2018), pp. 1-17. https://doi.org/10.1007/978-3-319-98180-2_1

Status: Postprint (Authors' version)

Brown, Caroline A. "Introduction: Women, Writing, Madness: Reframing Diaspora Aesthetics.” Madness in Black Women's Diasporic Fictions: Aesthetics of Resistance. Ed. Caroline A. Brown and Johanna X.K. Garvey. New York: Palgrave Macmillan, 2017. 1-16. Print.

Brown, Caroline A., and Johanna X.K. Garvey, eds. Madness in Black Women's Diasporic Fictions: Aesthetics of Resistance. New York: Palgrave Macmillan, 2017. Print.

Cassin, Frieda. With Silent Tread. Antigua: G.A. Uphill, Printer and Bookbinder, ca 1890. Print.

Chariandy, David. Soucouyant. Vancouver: Arsenal Pulp, 2007. Print.

Collins, Merle. The Colour of Forgetting. London: Virago, 1995. Print.

Dash, J. Michael. "The Madman at the Crossroads: Delirium and Dislocation inCaribbean Literature.” Profession (2002): 37-43. Print.

Díaz, Junot. The Brief Wondrous Life of Oscar Wao. New York: Faber, 2007. Print.

- “The Cheater's Guide to Love.” This Is How You Lose Her. By Díaz. New York: Riverhead, 2012. 173-213. Print.

Donnell, Alison. "Caribbean Queer: New Meetings of Place and the Possible in Shani Mootoo’s Valmiki’s Daughter.” Contemporary Women’s Writing 6.3 (2012): 213-32. Print.

—. "Introduction.” Pocomania and London Calling. By Una Marson. Kingston: Blouse and Skirt, 2016. ix-xxvi. Print.

Douglas, Marcia. The Marvellous Equations of the Dread. Leeds: Peepal Tree, 2016. Print.

Fanon, Frantz. Black Skin, White Masks. 1967. Trans. Charles Lam Markmann. London: Pluto, 1986. Print. Trans. of Peau noire, masques blancs. Paris: Seuil, 1952. Print.

Garvey, Johanna X.K. “Conclusion: Moving beyond Psychic Ruptures.” Madness in Black Women's Diasporic Fictions: Aesthetics of Resistance. Ed. Caroline A. Brown and Johanna X.K. Garvey. New York: Palgrave Macmillan, 2017. 293-310. Print.

Gilkes, Michael. "Creative Schizophrenia: The Caribbean Cultural Challenge.” The Third Walter Rodney Memorial Lecture, December 1986, Centre for Caribbean Studies, University of Warwick. Print.

Gramaglia, Letizia. “Representations of Madness in Indo-Caribbean Literature.” Diss. U of Warwick, 2008. Web. 5 Feb. 2018. 
Bénédicte Ledent, Evelyn O’Callaghan, and Daria Tunca” “'Madness Is Rampant on This Island': Writing Altered States in Anglophone Caribbean Literature", in Madness in Anglophone Caribbean Literature: On the Edge, ed. Bénédicte Ledent, Evelyn O’Callaghan, and Daria Tunca (New York: Palgrave Macmillan, 2018), pp. 1-17. https://doi.org/10.1007/978-3-319-98180-2_1

Status: Postprint (Authors' version)

Harrison, Sheri-Marie. “Fighting Madness, Making Caribbeanness.” Anthurium: A Caribbean Studies Journal 12.2 (2015). Web. 5 Feb. 2018.

James, Marlon. John Crow’s Devil. New York: Akashic, 2005. Print.

John, Marie-Elena. Unburnable. New York: Amistad, 2006. Print.

Josephs, Kelly Baker. Disturbers of the Peace: Representations of Madness in Anglophone Caribbean Literature. Charlottesville: U of Virginia P, 2013. Print.

Kincaid, Jamaica. The Autobiography of My Mother. 1996. New York: Plume, 1997. Print.

Lovelace, Earl. Salt. London: Faber, 1998. Print.

Mais, Roger. The Hills Were Joyful Together. 1953. London: Heinemann, 1981. Print.

Marson, Una. Pocomania and London Calling. Kingston: Blouse and Skirt, 2016. Print.

McCrink, James. “Imperial Illness: Considering the Trope of Madness in Michelle Cliff's No Telephone to Heaven.” MA thesis. Florida International U, 2017. Web. 5 Feb. 2018.

Miller, Kei. Augustown. London: Weidenfeld, 2016. Print.

Mootoo, Shani. Cereus Blooms at Night. 1996. New York: Harper Perennial, 1999. Print.

O’Callaghan, Evelyn. “Interior Schisms Dramatised: The Treatment of the 'Mad' Woman in the Work of Some Female Caribbean Novelists." Out of the Kumbla: Caribbean Women and Literature. Ed. Carole Boyce Davies and Elaine Savory Fido. Trenton: Africa World, 1990. 89-109. Print.

Persaud, Ingrid. If I Never Went Home. London: Blue China, 2013. Print.

Peters, Erskine. “The Theme of Madness in the Plays of Derek Walkcott.” CLA Journal 32.2 (1988): 148-69. Print.

Phillips, Caryl. A Distant Shore. New York: Knopf, 2003. Print.

—. In the Falling Snow. London: Harvill, 2009. Print.

- Strange Fruit. Ambergate: Amber Lane, 1981. Print.

. Where There Is Darkness. Ambergate: Amber Lane, 1982. Print.

Rhys, Jean. Wide Sargasso Sea. 1966. London: Penguin, 2000. Print.

Riley, Joan. The Unbelonging. London: Women’s Press, 1985. Print.

Scalinci, Francesca. “'Step[ping] over the Threshold into Otherness': Representations of Insanity in Roger Mais’s First Novel.” Ex-centric Writing: Essays on Madness in Postcolonial Fiction. Ed. Susanna Zinato and Annalisa Pes. Newcastle upon Tyne: Cambridge Scholars, 2013. 119-34. Print.

Smith, Zadie. White Teeth. London: Hamilton, 2000. Print. 
Bénédicte Ledent, Evelyn O’Callaghan, and Daria Tunca” “'Madness Is Rampant on This Island': Writing Altered States in Anglophone Caribbean Literature", in Madness in Anglophone Caribbean Literature: On the Edge, ed. Bénédicte Ledent, Evelyn O’Callaghan, and Daria Tunca (New York: Palgrave Macmillan, 2018), pp. 1-17. https://doi.org/10.1007/978-3-319-98180-2_1

Status: Postprint (Authors' version)

Thieme, John. "Becoming a Madman, Becoming a Madwoman: Ex-centricity in Caribbean Writing.” Ex-centric Writing: Essays on Madness in Postcolonial Fiction. Ed. Susanna Zinato and Annalisa Pes. Newcastle upon Tyne: Cambridge Scholars, 2013. 95-118. Print.

Walcott, Derek. Dream on Monkey Mountain. Dream on Monkey Mountain and Other Plays. By Walcott. 1970. New York: Noonday, 1999. 207-326. Print.

Warner-Vieyra, Myriam. As the Sorcerer Said. Trans. Dorothy S. Blair. London: Longman Drumbeat, 1982. Print. Trans. of Le Quimboiseur l'avait dit. Paris: Présence africaine, 1980. Print.

Zinato, Susanna, and Annalisa Pes, eds. Ex-centric Writing: Essays on Madness in Postcolonial Fiction. Newcastle upon Tyne: Cambridge Scholars, 2013. Print.

—. "Introduction." Ex-centric Writing: Essays on Madness in Postcolonial Fiction. Ed. Susanna Zinato and Annalisa Pes. Newcastle upon Tyne: Cambridge Scholars, 2013. 1-23. Print. 